\title{
The Number of Visitor of the Class Pandemic Time Corona Virus Disease Limit During 2019 Based on Internet of Thing
}

\author{
M.Zakuan Agung ${ }^{1,}$ Eka Susanti ${ }^{1, *}$ Suzan Zefi ${ }^{1}$ R.A Halimahtussa'diyah ${ }^{1,}$ \\ Rapiko Duri ${ }^{1}$ \\ ${ }^{I}$ Department of Polytechnic Sriwijaya, Jalan Srijaya Negera, Bukit Besar, Palembang - Indonesia \\ *Corresponding author. Email: ekasusanti@polsri.ac.id
}

\begin{abstract}
Number of visitors to engineering laboratory restrictions were carried out, because it could lead to crowds of students, resulting in the transmission of the SARS-CoV-2 virus that causes covid-19. The Telecommunications Engineering Laboratory is one of the facilities at the Sriwijaya State Polytechnic, which is used by all students to understand practically the telecommunication field. The design and manufacture of this tool aims to create a laboratory environment that is in accordance with health protocols in order to prevent transmission of CoronaVirus Disease 2019 (Covid-19). The system for limiting the number of visitors to the telecommunications engineering laboratory uses RFID (Radio Frequency Identification), Magnetic Sensors, Webcams and Touchless Buttons as input functions. This system uses Arduino Mega 2560 and Raspberry Pi 3 as the system's main controller processes. Component output using Magnetic door lock, LCD 16x2, LED, Relay, and Warning Light LED. Magnetic door lock functions as a door lock, $16 \times 2 \mathrm{lcd}$ as a monitoring system work process, relay as a switch or switch to disconnect and connect electric current, led and warning light led as an indicator.
\end{abstract}

Keywords: Auto, Digital system CoronaVirus Disease 2019, Arduino Mega 2560 Raspberry Pi 3, Touchless Button

\section{INTRODUTION}

Director General of Vocational Education (Dirjen Dikti), Wikan Sakarinto assesses that the policy to open face-to-face lectures is very good, especially for learning hands-on. There are several aspects that must be adhered to when conducting face-to-face learning. These requirements include checking body temperature, eliminating activities that have the potential to invite crowds, providing hand washing facilities, students are required to use three-layer cloth masks, maintain a minimum distance of 1.5 meters and limit room use to a maximum of $50 \%$ capacity per room and a maximum of 25 people. If the tertiary institution has fulfilled various requirements consisting of preparation, implementation, and monitoring, then all forms of face-to-face learning can be implemented. The laboratory is one of the supporting facilities available at the Sriwijaya State Polytechnic which is used by students for the implementation of practicum courses. Each practicum consists of several modules that must be completed by each student. Telecommunications Engineering Laboratory is one of the laboratories at the Sriwijaya State Polytechnic, which is used by all students to understand practically the telecommunications field. The various kinds of practicum held at the Telecommunications Engineering Laboratory include; practicum of signal processing, telecommunication electronics, transmission line, measurement, microprocessor, multimedia technology and others.

The number of practicums carried out at the Telecommunications Engineering Laboratory, of course, can cause a crowd of students.

This visitor limiting device is designed using several components, including arduino mega 2560 and raspberry pi as a microcontroller, RFID to activate the device, touchless button to trigger the door to open and to count the number of visitors, webcam functions as a visitor counter, Magnetic door lock to lock the door 
when it reaches the maximum number, the warning light LEDas an indicator of the full room, and the LCD serves to display the number of people in the laboratory. In addition, the number of visitors can also be accessed remotely by using the website, which to be able to access the website must be connected to the internet with a stable network connection. This is what is called an Internet of Things.

\section{SUPPORTING THEORY}

\section{Webcam}

Webcam is a combination of the words web and camera. Webcam itself is a term for cameras real-time whose images can be accessed or viewed via the internet,programs instant messaging such as Yahoo Messenger, AOL Instant Messenger(AIM), Windows Live Messenger, and Skype, and others. The term "webcam" itself refers to the type of camera used for a web-based service. The webcam itself is usually used for remote conference purposes or also as a monitoring camera [3].

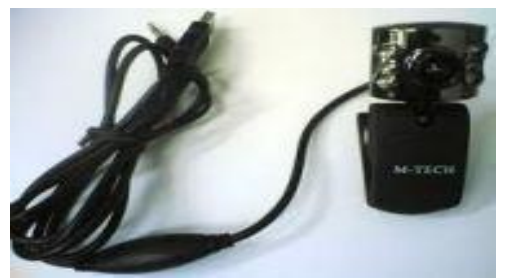

Figure 1 Webcam

\section{Radio Frequency Identification}

Radio Frequency Identification is a wireless technology that utilizes electromagnetic waves (RF). This RFID technology is able to automatically identify the presence of a person or an object by transferring information from an RFID Tag to a reader [4].

In Figure 2, is the RFID RC522, in this device the function of RFID is to activate and deactivate is the device.

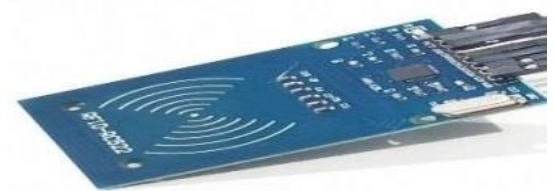

Figure 2 Radio frequency indentification RC522

\section{Magentic Sensor MC-38}

Magnetic Sensor MC-38 is a door opening/detection module that works based on electromagnetic principles. Under normal conditions (sensors and magnets are not close together), the switch is in an open condition (normally open/NO). In the active condition when the sensor and magnet are close together or the door is closed, the switch is in a closed circuit with a resistance value of $\pm 4 \Omega[5,6]$.

In Figure 3, the Magnetic Sensor MC- 38 is used as a door position detector in the telecommunications engineering laboratory.

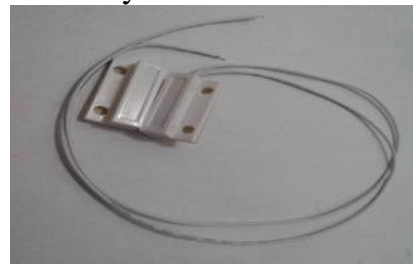

Figure 3 Magnetic sensor MC-38

\section{Internet of Thing}

Internet of Things is a structure in which the objects, people are provided with an exclusive identity and the ability to move data through the network without requiring both directions between humans that is the source to the destination or human interaction to the computer. The Internet of Things is a very promising scientific development to optimize life based on intelligent sensors and smart devices that work together through the internet $[11,12]$.

\section{DESIGN SYSTEM}

Design is an activity to plan, realize and develop the function of a tool by considering the value for the user. To realize the tool made, the first step is to make a design or sketch as a basic reference in making the tool. The purpose of designing a tool is to facilitate the manufacture of tools, to get a good device as expected, taking into account the use of components that are economical and easily available in the market. A block is one of the most important parts in the design of a tool, because from this block circuit diagram we can know how the whole circuit works. So that the entire block diagram of the circuit will describe how the work of the tool is to be made.

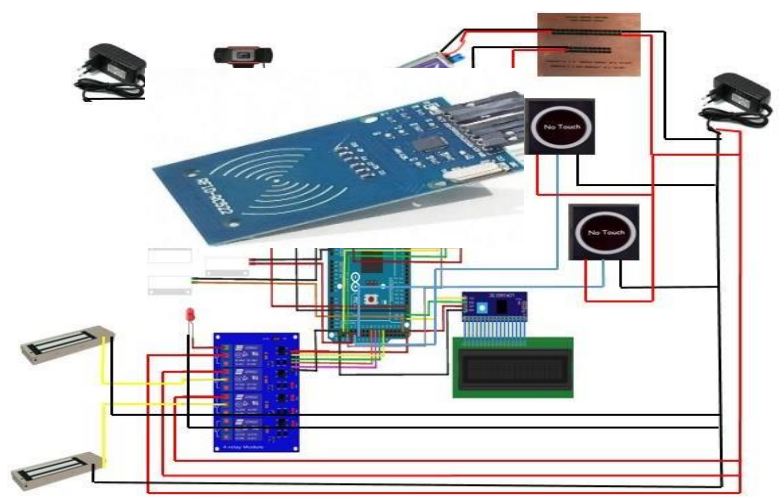

Figure 4 Circiut Diagram Design 


\section{CURRENT RESULT}

Result of the design of a visitor limiting device that has been designed as a whole which will then be used to limit the number of visitors to the telecommunications engineering laboratory, so as to create a laboratory environment that is in accordance with health protocols.

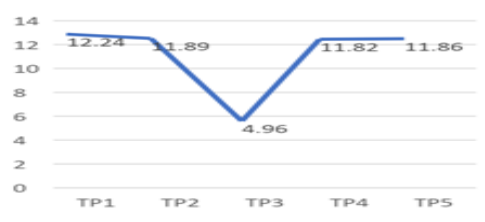

Figure 5 Rate voltage in active condition for Test Point 1, Test Point 2, Test Point 3,Test Point 4,Test Point 5

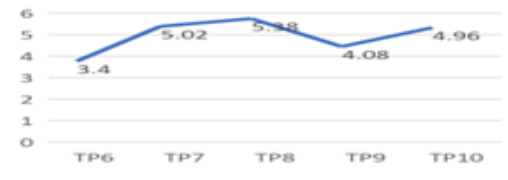

Figure 6 Rate voltage in active condition for Test Point 6, Test Point 7, Test Point 8,Test Point 9, Test Point 10



Figure 7 Rate voltage in active condition for Test Point 11, Test Point 12, Test Point 13, Test Point 14,Test Point 15

\section{CONCLUSION}

The hardware device that limits the number of visitors to this telecommunications engineering laboratory uses RFID (Radio Frequency Identification) to activate the device so that it can work.

This device limiting the number of laboratory visitors can limit the number of people in the laboratory automatically by locking the door when it has reached the maximum limit specified.

Webcam and Touchless function as a means of calculating the number of visitors to the telecommunications engineering laboratory which will then be displayed on the LCD.
This device limiting the number of visitors can be used to limit the number of visitors to the Telecommunications Engineering Laboratory so as to reduce crowds and create a laboratory environment that is in accordance with health protocols.

\section{AUTHORS' CONTRIBUTIONS}

Contribution to the authors is making research data collection and disign program applications.

\section{ACKNOWLEDGMENTS}

In writing this paper, the researcher has conducted several sample trials with reference to references as reference material, to improve this paper.

\section{REFERENCES}

[1] Arifin, J., \& Zulita , LN (2016). Automatic Murottal Design Using Arduino Mega 2560 Microcontroller. Journal of Media Infotama, 12(1).

[2] Tanjung, A. (2015). Application of Liquid Crystal Display (LCD) 16x2 as a Display on Coconut Milk Auto Machine (Doctoral dissertation, Sriwijaya StatePolytechnic).

[3] Abidin, Riswan. 2016. Pengertian Virtual Reality. https://teknojurnal.com.

[4] Murdika, U. (2015). Design and Build Automatic Turn Counter Equipment Based on Radio Frequency Identification (RFID). Electricians, 9(2), 73-78.

[5] Syabibi, MK, \& Subari, A. (2016). Design and Build a WEB-Based Home Security Monitoring System Using Raspberry PI B+ As Server and Control Media. Echo Technology, 19(1), 22-29.

[6] Phillips, Rob. The developer's handbook to interactive multimedia: a practical guide for educational applications. London: Kogan Page Ltd,1997.

[7] Sadiman, A.S. dkk., Media Pendidikan: Pengertian, Pengembangan dan Pemanfaatannya, Bandung: Remaja Rosdakarya, 2002.

[8] Siswanto, S., Utama, GP, \& Gata, W. (2018). Room security with Dfrduino Uno R3, Mc-38 sensor, pear, sms notification, twitter. RESTI Journal (System Engineering and 2(3), 697-707.

$$
\text { Information Technology), }
$$

[9] Muhammad, H. (2017). Infusion Monitoring System Using Arduino Mega 2560 (Doctoral dissertation, Alauddin State Islamic University Makassar).

[10] Binanto, Iwan. 2010. Multimedia Dasar-Dasar Teori dan Pengembangannya. Yogyakarta: Deepublish.

[11] Nurkamiden, MR, Najoan, ME, \& Putro, MD 
(2017). Design and Build a Web Server-Based Electrical Device Control System Using a Raspberry Pi Mini PC Case Study of the Engineering Faculty Building, Sam Ratulangi University. Journal of Informatics Engineering, 11(1).

[12] Kurniawan, EMW (2020). Automatic Home Door Lock With Magnet Door Lock Based on Internet of Things Using Telegram Home Bot. $e$ NARODROID, 6(1), 29-33.

[13] M. Mihelj, D. Novak and S. Begus, Virtual Reality Technology and Applications, Vol. 68, London Springer, 2014.

[14] Ausburn, L J. 2009. A Cross-case Analysis of Gender Issues In Dekstop Virtual Reality Learning Environments. Journal of Industrial Teacher Education, 46(3) 51-89.
[15] Ausburn, L J. 2004. Dekstop Virtual Reality: A Powerful New Technology for Teaching and Research in Industrial Teacher Education. Journal of Industrial Teacher Education.41(4). http://scholar.lib.vt.edu/ejournals/JITE/v41n4/ ausburn .html.

[16] Hendratman, Hendi. 2015. The Magic of Blender 3D Modelling. Bandung : Informatika.

[17] Moeleong, L. 2013. Implementasi Cluster Computing Untuk Render Animasi. E-Jurnal Teknik Elektro dan Komputer Universitas Sam Ratulangi Manado.

[18] CG Channel. 2017. Soft8Soft releases Verge3D.

[19] Sarjana, Rapiko D., dan Sangkut I. 2019. "Bahan Ajar Praktek Digital Jurusan Teknik Elektro Politeknik Negeri Sriwijaya”. 2019. Palembang. 